JEL O 330

ЦИГАНОВ С.A.,

д-р екон. наук, проф.

Київський наиіональний університет

імені Тараса Шевченка

вул. Мельникова, 36/1, м. Київ, Україна, 04119

E-mail:S_Tsyganov@ukr.net

\title{
СИЗОНЕНКО В.О.
}

кандидат екон.наук, дои.

Київський національний університет

імені Тараса Шевченка

вул. Мельникова, 36/1, м. Київ, Україна, 04119

E-mail:viktor.sizonenko@ukr.net

\section{ГЛОБАЛІЗАЦІЙНА ТРАНСФОРМАЦІЯ ІННОВАЦІЙНОЇ СКЛАДОВОЇ В СИСТЕМІ ПРІОРІТЕТІВ ЕКОНОМІЧНОГО РОЗВИТКУ}

Досліджено особливості інноваційного розвитку в Україні в умовах посилення глобальної конкуренції та доведено необхідність розробки власної моделі інноваційної економіки, розвитку інноваційного підприємництва, сучасних інноваційно-інформаційних технологій, посилення інноваційного характеру виробничої діяльності, адже світовий ринок діє за допомогою нововведень, а інноваційне прискорення $\epsilon$ основою його сталого розвитку.

Ключові слова: глобалізація, інновачійний розвиток, інноваційно-інформаційні технологї, конкуренція, підприємництво.

TSYGANOV S.A.,

Dr.Sc. (Economics), Prof.

Taras Shevchenko National University of Kyiv

Melnikova 36/1 Str., Kyiv, Ukraine

E-mail:S_Tsyganov@ukr.net

SIZONENKO V.O.

$\mathrm{PhD}$ in Economics, Associate Professor

Taras Shevchenko National University of Kyiv

Melnikova 36/1 Str., Kyiv, Ukraine

E-mail:viktor.sizonenko@ukr.net

\section{GLOBALIZATION TRANSFORMATION OF INNOVATION COMPONENT IN A SYSTEM OF PRIORITIES IN ECONOMIC DEVELOPMENT}

This article explores the nature and characteristics of the innovation economy, its place and role in the world economy. Considered the world experience of regulation of innovative development in the context of the challenges of global competition. Determined methodological basis for the formation of international competitive advantages of the country in the global innovation space. Proved that the innovative development of national economies under global transformations due to the necessity of forming a model of open economy, which would be competitive and innovative optimally combine the available internal resources of the economic system and the benefits of international cooperation in the field of innovation in the increasingly global competition.

Proved that innovation in terms of one of the key factors in international competitiveness of national economies is their innovative capacity, which reflects the potential for the creation and use of modern innovative technologies. The efficiency of the national innovation system primarily depends on a complex system of interaction between enterprises that produce innovative products, research organizations to develop and help implement into production new products and technologies, which allows to optimize the use of available resources innovation and create effective innovative environment that is catalyst for generating new innovative technologies.

Grounded conditions and factors of formation and development of innovative economy in Ukraine. A public policy measures that aim to transform the transformation of the national innovation system, the development of innovative potential and a favorable investment climate, innovative and innovation environment in Ukraine.

Key words: globalization, innovation development, innovation and information technologies, competition, network economy. 
Постановка проблеми та її зв'язок з важливими науковими та практичними завданнями. Характерною ознакою сучасного розвитку світового господарства i міжнародних економічних відносин є глобалізація, яка відкриває великі можливості для прискореного розвитку окремих країн, суб'єктів малого i середнього бізнесу за рахунок інтенсивного формування i використання їх інноваційного потенціалу. Водночас глобальні тенденції обумовлюють трансформацію світового економічного простору, загострюють конкуренцію в сфері науково-технічних розробок та їх технологічного освоєння, обмежують доступ до фінансових і інвестиційних ресурсів. Вони містять істотні загрози інноваційній складовій економічного зростання, здатні справляти негативний вплив на національні системи господарювання або окремі сфери і види діяльності, що веде до асиметрії світового господарства. Глобалізації, незважаючи на синергетичні ефекти, притаманні суперечності, рухливість факторів, що забезпечують іiі динаміку, мінливість складових механізму впливу на соціально-економічний розвиток. Особливо гостро вплив глобалізаційних процесів відчувається в інноваційно-інвестиційній сфері. Це пов'язано із зростанням вартості проведення НДДКР, значним поширенням інформаційно-комунікаційних технологій, посиленням мережевого характеру міжнародного економічного співробітництва.

Тому, своєчасне виявлення і аналіз тенденцій змін в інноваційній складовій економічно розвинених країн, оцінка та прогнозування ї впливу на економічний розвиток окремих та суб'єктів господарювання потребує дослідження i всебічного врахування при визначенні пріоритетів економічного розвитку.

Аналіз останніх публікацій по проблемі. Глобалізаційна трансформація інноваційної складової економічного розвитку $є$ проблемою, яка викликає підвищений інтерес, активно аналізується як науковцями, так i бізнес-практиками. Дослідження трансформації світового економічного простору, виявлення впливу глобалізації на розвиток національних інноваційних систем, зрушення у процесах стратегічного менеджменту ТНК проведені вітчизняними і зарубіжними ученими: М. Кастеллом, С. Кохеном, Ф. Кардосом, Д. Лук'яненком, А. Поручником, В. Сизоненком, Ф. Хайеком, Г. Хікманом, О. Хотяшевою, О. Шевчуком та ін., що підтверджують домінування в соціально-економічних процесах інноваційної складової, яка забезпечує конкурентоспроможність продукції тієї чи іншої країни на світових ринках.

Виділення невирішених раніше частин загальної проблеми. Аналіз існуючих підходів в економічній літературі щодо проблем інноваційного розвитку показує, що у багатьох дослідженнях в меншій мірі зосереджується увага на трансформації інноваційної складової під впливом глобалізації, iï результативності для країн з різним рівнем економічного розвитку і відкритості, в тому числі і для України. По суті відсутні важливі прикладні роботи щодо застосування положень теорії глобалізації в умовах фінансових та інвестиційних обмежень інноваційного розвитку, невизначеності інституціонального середовища.

Формулювання цілей дослідження. В даному дослідженні пропонується комплексно розглянути сучасні тенденцій розвитку глобалізаційних процесів і обгрунтувати необхідність та напрямки трансформації національної інноваційної системи в умовах глобальної конкуренції для формування відновлювального тренду економічного зростання.

Виклад основних результатів та їх обгрунтування. Існує декілька версій визначення глобалізації, основних ознак цього процесу. По-перше, виробнича версія, в якій матеріальною основою становлення і розвитку глобалізаційних процесів справедливо вважається поглиблення поділу праці та посилення науково-технологічного та виробничого кооперування між різними країнами, їх господарюючими суб'єктами. Згідно цієї версії, поглиблення співробітництва веде до їх взаємозалежності, взаємопроникнення підсистем інноваційної діяльності, обумовлює інтернаціоналізацію виробництва, і в кінцевому рахунку зміцнює позиції ТНК.

По-друге, фінансова версія, згідно з якою у світовому економічному просторі відбувається зростання взаємодії і взаємозалежності фінансово-економічних систем, що обумовлює особливі умови доступу компаній на фінансові ринки.

По-третє, інституціональний підхід, суть якого полягає у положенні про зміну співвідношення ендогенних та екзогенних факторів, послабленні можливостей національних держав самостійно формувати ефективну незалежну економічну політику при одночасному посиленні регулятивного впливу новостворених міждержавних, міжнародних економічних інституцій на вирішення проблем економічного зростання глобального характеру.

По-четверте, версія взаємодоповнення економік різних країн за рахунок розширення масштабів обміну, урізноманітнення та інтенсифікації руху товарів, капіталів, трудових ресурсів з відповідною 
адаптацією форм регулювання на основі застосування єдиних стандартів, цінностей, принципів функціонування інтегрованих економічних систем.

До найглобалізованих країн світу в 2015 році належали Ірландія (значення індексу 92,17), Бельгія $(91,61)$, Нідерланди $(91,33)$, Австрія $(90,48)$, Сінгапур $(22,63)$. Динаміка українського індексу глобалізації характеризується поступовим зростанням: якщо у 2010 році цей показник становив 65,64 , то у $2015-68,85$ [7].

Головними гравцями світового ринку інновацій є ТНК та їх стратегічні групи, створені в різних країнах. Дослідницькі і впроваджувальні підрозділи ТНК зосереджують свої зусилля переважно на прикладних дослідженнях, результатом яких є інновації із швидким результатом. Водночас для забезпечення стратегічних конкурентних переваг розробляється і впроваджується радикальні, базові інновації, які є більш ризикованими та капіталомістськими.

Ядром глобалізаційної трансформації у світовому економічному просторі стали інформаційнокомунікаційні технології, знання, які виступають головним джерелом поширення інновацій через мережеву структуру. Позитивним $є$ розробка контрольних показників та індикаторів розвитку інформаційного суспільства в нашій країні (див. табл. 1).

Таблиця 1

Контрольні показники та індикатори розвитку інформаційного суспільства в Україні *

\begin{tabular}{|c|c|c|c|c|}
\hline \multirow[b]{2}{*}{ № } & \multirow[b]{2}{*}{ Найменування індексу } & \multicolumn{3}{|c|}{ Значення індексу } \\
\hline & & $\begin{array}{c}2013 \\
(\text { І етап) }\end{array}$ & $\begin{array}{c}2015 \\
\text { (II етап) }\end{array}$ & $\begin{array}{c}2020 \\
\text { (III етап) }\end{array}$ \\
\hline 1 & $\begin{array}{l}\text { Глобальний індекс конкурентоспроможності (WEF } \\
\text { Global Competitiveness Index) }\end{array}$ & 80 місце & 65 місце & 50 місце \\
\hline 2 & $\begin{array}{l}\text { Індекс технологічної готовності (WEF Technological } \\
\text { Readiness Index) }\end{array}$ & 80 місце & 65 місце & 50 місце \\
\hline 3 & $\begin{array}{llll}\text { Iндекс } \\
\text { Readiness Index ) }\end{array}$ & 73 місце & 65 місце & 60 місце \\
\hline 4 & $\begin{array}{l}\text { Е-готовність уряду (Government readiness) }-122 \\
\text { місце із } 138 \text { країн }\end{array}$ & 120 місце & 90 місце & 60 місце \\
\hline 5 & Використання урядом IКТ (Government usage) & 73 місце & 65 місце & 55 місце \\
\hline 6 & $\begin{array}{llll}\text { Рейтинг за електронною } & \text { готовністю } & \text { (EIU } & \text { e- } \\
\text { Readiness Ranking) } & & & \end{array}$ & 63 місце & 58 місце & 50 місце \\
\hline 7 & $\begin{array}{l}\text { Індекс електронного уряду ООН (UN e-Government } \\
\text { Index) }\end{array}$ & 65 місце & 60 місце & 50 місце \\
\hline 8 & Частка користувачів Інтернет & $50 \%$ & $75 \%$ & $90 \%$ \\
\hline 9 & $\begin{array}{l}\text { Частка електронного документо-обігу між органами } \\
\text { державної влади в загальному обсязі документообігу }\end{array}$ & $25 \%$ & $50 \%$ & $75 \%$ \\
\hline 10 & $\begin{array}{l}\text { Частка документів Національного архівного фонду, } \\
\text { переведених в електронну форму, в загальному } \\
\text { обсязі суспільно-значущих документів }\end{array}$ & $5 \%$ & $15 \%$ & $30 \%$ \\
\hline 11 & $\begin{array}{l}\text { Частка бібліотечних } \\
\text { електронну формдів, в загальному обсязі фондів }\end{array}$ & $5 \%$ & $20 \%$ & $50 \%$ \\
\hline 12 & $\begin{array}{l}\text { Показник охоплення населення цифровим наземним } \\
\text { ефірним телерадіомовленням, включаючи якісне } \\
\text { телебачення - } 100 \%\end{array}$ & $15 \%$ & $50 \%$ & $100 \%$ \\
\hline 13 & $\begin{array}{l}\text { Частка адміністративних послуг в електронному } \\
\text { вигляді }\end{array}$ & $10 \%$ & $75 \%$ & $90 \%$ \\
\hline 14 & $\begin{array}{l}\text { Частка населення та суб'єктів господарювання як } \\
\text { користувачів адміністративних послуг } \\
\text { електронному вигляді } \\
\text { в }\end{array}$ & $10 \%$ & $75 \%$ & $90 \%$ \\
\hline
\end{tabular}
forecast]

* Джерело: [http//www.rdmag.com/digital-editions/2014/12/2015-r-d-magazine-global-funding-

Особливо місце у визначенні основних ознак глобалізації належить інноваційним процесам, спільній діяльності в науково-технологічній сфері, 3 ефективністю яких пов'язують конкурентоспроможність національних економік, окремих корпорацій, рух капіталів та утворення 
високотехнологічних кластерів. Ці процеси сприяють формуванню конкурентних переваг, істотно впливають на структурні зрушення в економіці, ефективне використання інтелектуального та людського капіталу, дозволяють підвищити значущість країни у світовому поділі праці як виробника високотехнологічної продукції та послуг. Орієнтація на безперервний пошук і створення нових джерел конкурентних переваг спонукає до активізації інноваційної діяльності у спільному науковотехнічному та технологічному просторі 3 використанням новітніх інноваційно-комунікаційних технологій, розробки й прийняття управлінських рішень.

Під впливом глобалізації інноваційний розвиток набуває в успішних країнах відповідного динамізму завдяки зростаючому попиту на високотехнологічну продукцію $\mathrm{i}$ послуги як в національній економіці, так і за іiі межами. Поява нових можливостей переливання фінансових та інших ресурсів у різні світові ринки змінює співвідношення економічних потенціалів різних країн. Підвищення складності та наукоємності наукових розробок вимагає інноваційної діяльності до співробітництва.

Підтвердженням цих процесів є перехід до «відкритих» інновацій, децентралізованого проведення НДДКР з широким використанням аутсорсингу, динамічних холдингових структур, на чому наполягають дослідники [2, с. 59-66]. Нових рис набуває і глобальна конкуренція: колишні конкуренти утворюють стратегічні альянси, в яких поєднується конкуренція із співробітництвом. За рахунок створення альянсу або входження до цього нових членів відбувається масштабне фінансування НДДКР, скорочення витрат на поточну організацію виробництва, зниження інноваційних ризиків, більш інтенсивний обмін технологіями. Глобалізація бізнесу розширює можливості комбінування стратегій горизонтальної, вертикальної та конгломератної диференціації, формування споживчого ринку для реалізації поступальної інноваційної стратегії [3, с.48-51].

Тим самим за справедливою оцінкою дослідників [8], вичерпується кейнсіанська модель розвитку національних процесів, що відбуваються всередині країни. На зміну цій моделі прийшли ідеї глобалістичного економічного необералізму Ф.А. Хайєка [9], представників «Лондонської школи» та монетаристської доктрини М. Фрідмана [10] і його «Чиказької школи». Інформаційні технології визначили трансформацію інноваційних процесів, вирішальною мірою завдяки потужними ТНК, річний бюджет кожної з 500 наймогутніших перевищує ВНП багатьох країн світу [8, с. 143].

В кінцевому рахунку це обумовлює інтернаціоналізацію науково-технічної та інноваційної діяльності, сприяє інтелектуалізації спільного виробництва, прискоренню технологічного оновлення спільного виробництва, галузей та зміцненню життєвого циклу продукції.

Існують і інші тенденції глобалізаційної трансформації інноваційної складової, а саме: зростання частки інвестицій, що спрямовуються на розвиток людського капіталу, збільшується питома вага витрат на НДДКР, в загальному обсязі витрат [2], що сприяє відповідному зростанню доданої вартості в продукції та послугах.

Важливим результатом глобалізаційної трансформації інноваційної складової є зміна характеру ринкової конкуренції. Для великих корпорацій посилення конкуренції на внутрішньому ринку обмежує можливості використання потужного інноваційного потенціалу і одночасно стимулює вихід на світові ринки. Урахування нових ринкових тенденцій передбачає формування організаційних форм реалізації інновацій, адекватних потребам світового ринку, створення нових компетенцій щодо розробки радикальних інновацій, диверсифікація джерел інновацій [6].

В контексті визначення глобалізаційої трансформації інноваційної складової економічного розвитку України, посилення іiі впливу на розвиток національного господарства для України загострюється проблема вибору моделі інноваційного розвитку, структурної модернізації економіки. Незважаючи на визначення ролі інноваційно-інвестиційної моделі модернізації економіки на державному рівні, Україна втратила позитивну динаміку розвитку. Інноваційні процеси не впливають на темпи і якість економічного зростання, оскільки частка інноваційно активних підприємств і обсяг інноваційної продукції вкрай малі [11, с. 78].

Основними причинами незадовільного стану інноваційної діяльності, невизначеності перспектив їі розвитку є:

- екстенсивний характер інноваційних процесів, які відбуваються шляхом використання наявного обладнання та застарілих технологій,що звужує існуючий інноваційний потенціал більшості підприємств.

- фінансові обмеження інноваційної діяльності підприємств, низька умотивованість фінансовокредитних установ в інвестиційному забезпеченні в умовах нестабільності економіки, що підвищує ризикованість участі банків та інших фінансових установ. 
- не відбувається широкого використання наявних наукових вітчизняних та зарубіжних розробок, що веде до згортання НДДКР та звуження попиту на інновації.

- відсутність оптимальних організаційних форм інтеграції промислових підприємств 3 відповідним промисловим капіталом, фінансово-кредитних установ 3 фінансовим капіталом та науково-дослідних і дослідно-впроваджувальних організацій з інтелектуальним капіталом, що не дозволяє досягнути синергійного ефекту їх взаємодії.

- не виправдовується очікування економічного ефекту від суб'єктів малого підприємництва, їх питома вага в загальній кількості інноваційно активних підприємств мізерно мала (близько $0,1 \%$ ).

- корпоративні інтеграційні утворення вибудовують політику нарощування конкурентних переваг за рахунок отримання суб'єктами господарювання відповідних пільг та преференцій, тонізації частини комерційних операцій, що обумовлює утвердження «рентної» моделі конкуренції, не пов'язаної з використанням інноваційного потенціалу.

Реальний аналіз досвіду формування інноваційного потенціалу на різних рівнях свідчить, що в сучасних умовах він все більш переміщується на корпоративний рівень, що обумовлює необхідність всебічних досліджень процесів становлення розвитку та ефективного використання інноваційного потенціалу, на якому діють певні конкурентні переваги над замкненою інноваційною діяльністю. Так, в межах фінансово-промислових груп відбувається об'єднання промислового, фінансового й інтелектуального капіталу, які згідно закону синергії дають віддачу більш їх суми при самостійному фінансуванні. Але синергійний ефект цього об'єднання залежить від організаційної цілісності цієї системи, яка визначається складом системо утворюючих елементів, способами їх взаємодії, формами регулювання інтегрованої інноваційної діяльності.

Творець кластерної теорії М. Портер відзначив, що виробництва кластеру роблять один одному взаємну підтримку, а виробники з інших галузей кластера стимулюють НДДР і забезпечують кошти для швидкого поширення нововведень [12]. Під впливом сукупної дії ефектів масштабу, злиття окремих складових в єдину систему виникає інноваційний потенціал, що перевищує суму потенціалів окремих складових. Крім того, сучасний розвиток інформаційно-комунікаційних технологій сприяє формуванню так званих «віртуальних» кластерів, які здатні впливати на зміну структури й складу реальних кластерів.

Поряд із безперечними перевагами кластерної організації формування і розвитку інноваційного потенціалу слід визначити і деякі обмеження цього процесу. По-перше, склад учасників кластеру може доволі часто змінюватись, що може спровокувати негативні ефекти для інших учасників; подруге, в умовах глобалізації і використання сучасних інформаційних технологій географічна локалізація може виявитися контрпродуктивною; по-третє, кластер ний підхід не завжди дозволяє зосередити значні фінансові й інтелектуальні ресурси для виконання стратегічних завдань. Слід врахувати, що в Україні рівень інноваційної активності залишається недостатнім, що є наслідком слабої зорієнтованості інституційної, фінансової та банківської систем на підтримку прогресивної моделі розвитку інноваційної економіки. Не можна визнати задовільним й посередницькі організації, які стикують попит і пропозицію на інновації, сприяють венчурному фінансуванню.

На противагу промисловим або інноваційним категоріям, ФПГ створюється переважно шляхом акціонування, об'єднання матеріальних і нематеріальних активів. На відміну від кластер них об'єднань, ФПГ представлені як над фірмове утворення, тобто сукупність господарюючих суб'єктів 3 правами юридичних осіб, серед яких обов'язковим є фінансовий інститут. У складі цієї корпоративної структури створюється єдиний центр управління (центральна або головна компанія), яка реалізує відносини власності між учасниками групи через їх участь в спільному акціонерному капіталі. Але законодавство України акцентує увагу на домінуванні промислового капіталу, реалізації державних програм як обов'язкового атрибуту діяльності, а також виробництва кінцевої продукції .

Між тим, як свідчить світова практика, ФПГ є ефективним утворенням, 3 якого активізується інноваційна діяльність, створюється особливо сприятливі умови для розробки науково-технічних нововведень, їх промислового освоєння та комерціалізації результатіів. Це пояснюється з більш широкими можливостями фінансування та інвестування новітніх технологій, прискореного впровадження розробок у практику, використання міждисциплінарного характеру багатьох НДДКР, можливостями масового виробництва високотехнологічної та наукоємної продукції. Наприклад, понад половина наукових досліджень $Є С$ зосереджена у великих корпораціях, які мають для цього відповідні наукові кадри, матеріально-технічне та фінансове забезпечення НДДКР. Результатом використання такого інноваційного потенціалу в країнах $\mathrm{CC} є$ висока питома вага інноваційної продукції, яка досягає $60 \%$ в загальному обсязі продукції [11, с. 79]. 
В Україні склалася інша ситуація: більшість наукових і науково-технічних кадрів зосереджена у ВНЗ та НДІ академії наук. При цьому спостерігається тенденція їх зменшення в заводському (корпоративному) секторі. Так, у 2015 р. порівняно з 2001 р. відбулося зменшення численності науковців майже в 2,5 рази, а частка осіб, зайнятих дослідженнями і розробками в Україні становить приблизно 0,5\% від загальної кількості зайнятих при середньому значенні цього показника для країн $\mathrm{EC}-1,2 \%$.

У контексті глобалізації економіки важливе місце належить більш глибокому інтегруванню банківської системи України у європейський та світовий фінансовий та економічний простір. При цьому доцільно врахувати зрушення у сфері фінансування інноваційної діяльності, і передусім зростання витрат на НДДКР у ВВП. Так у Швеції частка витрат на НДДКР у ВВП в останні роки досягла 4,3\%, у Фінляндії - 3,5\%, Японії - 3,1\%, а в Ізраїлі цей показник зріс у понад два рази від 2,35\% у 1998 р. до 5,1\% у 2012 р. В абсолютних показниках лідером витрат на НДДР залишаються США (300 млрд. дол. США), Японія, а починаючи 32004 р. на трете місце виходить Китай із науковим бюджетом у 60 млрд. дол. США [6; 7].

Характерним є збільшення обсягів державного фінансування у порівнянні 3 приватним сектором, а для окремих країн $\mathrm{CC}$ - посилення фінансової допомоги наднаціональних структур у реалізації наукових програм, зокрема в Ірландії та Португалії. Проявом глобалізації є зростання в структурі джерел фінансування обсягів іноземного фінансування національних НДДКР, участь фінансових угрупувань у створенні технологічних альянсів, патентування за кордоном та патентуванні нерезидентами у певній країні.

Незважаючи на експортну орієнтацію ФПГ у цілому, пріоритетним напрямом використання інноваційного потенціалу повинна стати його орієнтація на внутрішній ринок, при цьому випуск високотехнологічної продукції має визначитися адекватним розвитком ринків збуту. Формування платоспроможного попиту на інновації сприяє розширенню можливостей фінансування розвитку інноваційного потенціалу ФПГ за рахунок як власних джерел, так і за рахунок інвестиційних ресурсів. Системність відтворення інноваційного потенціалу дозволить перетворити вітчизняні промислові групи у каталізаторів економічного зростання.

Висновки та перспективи подальших досліджень. Узагальнюючи досвід формування та ефективного використання інноваційного матеріалу інтегрованих корпоративних утворень в Україні, можна констатувати, що скоординованої та всеохоплюючої системи управління цими процесами поки ще не існує. Гальмується створення на основі ФПГ та кластерних механізмів розвитку інноваційної діяльності через економічну нестабільність в країні, певний дефіцит фінансових коштів та постійну загрозу інфляції, високий ризик. Відсутність економічної зацікавленості більшості господарюючих суб'єктів в реалізації нововведень, відсутність конкуренції на внутрішньому ринку науково-технічної продукції, посилення негативного впливу глобалізаційної трансформації становлять основні загрози для інноваційного розвитку економіки України, які потребують подальших наукових досліджень.

\section{ЛІТЕРАТУРА}

1. Управління міжнародною конкурентоспроможністю в умовах глобалізації економічного розвитку: монографія: У 2 т. - Т. 1 / за ред. Д.Г. Лук'яненка, А. М, Поручника. - К.: КНЕУ, - 2006. $816 \mathrm{c}$.

2. Глобальна економіка XX1 століття: людський вимір: монографія / за ред. Д.Г. Лук'яненка, А.М. Поручника. - К.: КНЕУ, 2008. - 420 с.

3. Хотяшева О.М. Стратегическое управление инновациями в современных компаниях / О.М. Хотяшева // Инициативы XX1 века. - 2009. - №4. - С.48-54.

4. Hickman G. Incubating Innovation / G. Hickman, Ch. Raia //Joumal of Business Strategy. - 2012. - Vol 23. No.3. - P. 14-18.

5. Castells. M. The Information Economy and the New International Division of Labor/ M. Castells. The New Global Economy in the Information Age: Reflections on our Changing World; M. Carneu, M. Castells, S. Cohen, F.Cardoso, eds - Pennsylvania State University Press, 1993. pp. 15-19.

6. Globalization of Innovation and R\&D // The Centennial Global Business Summit. Harvard Business School. - Summit Report. - 2015. - P. 2-12.

7. The Global Enabling Trade Report 2015 [Електронний ресурс] - Режим доступу: //www.weforvm.org/reports/global-enabling-trade-report-2014.

8. Шевчук О.Б. Інформаційно-технічна революція і ії роль у розвитку світової економіки / О.Б. Шевчук // Економіка і прогнозування. 2014, №3, с. 139-152. 
9. Хайек Ф.А. Пагубная самонадеянность: ошибки социализма / Ф.А. Хайек. - М.: Эконов, 1992. $-385 \mathrm{c}$.

10. Фридман М. Количественная теория денег / М. Фридман. - М.: Эльф-пресс, 1996. - 673с.

11. Сизоненко В.О. Механізми активізації інноваційної діяльності інтегрованих корпоративних структур / В.О. Сизоненко // Теоретичні та прикладні питання економіки: Збірник наукових праць. Вип. 27, т.1. - К.: ВПЦ «Київський університет», 2012. - С. 43-50.

12. Портер М. Конкуренция: пер. с англ. / М. Портер. - М. Изд. Дом-Вильям, $2001-495$ с.

\section{REFERENCES}

1. Lukynenko, D.G., \& Poruchnyk, A.M. (2006). Upravliniy mijnarodnoy konkurentospromojnosty v umovah globalizatsii ekonomichnogo rozvitku [Management an international competitiveness in the conditions of globalization of economic development: monograph] (Vols. 1-2; Vol. 1). D.G. Lukynenko (Ed.). Kyiv: KNEU [in Ukrainian].

2. Lukynenko, D.G., \& Poruchnyk, A.M. (2008). Globalna economika v XXI stolitiy: ludskiy vumir [Global economy of XXI of century: human measuring: monograph] D.G. Lukynenko (Ed.). Kyiv: KNEU [in Ukrainian].

3. Hotysheva, O.M. (2009). Strategicheskoe upravlenie innovatsiami v sovremennuh kompaniyah [The Strategic management by innovations in modern companies] Initsiativi XXI stolitiya - Initiatives of $X X 1$ of century, 4, 48-54 [in Russian].

4. Hickman, G., \& Raia Ch. (2012). Incubating Innovation. Jurnal Biznes strategiy - Joumal of Business Strategy. 23, 3, 14-18.

5. Castells M. The Information Economy and the New International Division of Labor. The New Global Economy in the Information Age: Reflections on our Changing World. Carnoy M., Castells M., Cohen S., Cardoso F., eds. University Park, Pennsylvania State University Press, 1993, pp. 15-43.

6. Globalization of Innovation of and of R\&D (2015). The Centennial Global Business Summit. Harvard Business School. Summit Report, 2-12.

7. The Global Enabling Trade Report 2015. Retrieved from: //www.weforvm.org/reports/globalenabling-trade-report-2015.

8. Shevchuk, O.B. (2014). Informatsiyna and tehnichna revolutsia i ii rol u rozvitku svitovoy economiki [Informatively-technical revolution and her role in development of world economy] Economika $i$ prognozuvania - Economy and prognostication, 3, 139-152 [in Ukrainian].

9. Hayek, F.A. (1992). Pagubnay samonadeyanost: oshibki sotsializma [The Pernicious conceit: errors of socialism]. Moskow: Ekonov [in Russian].

10. Frydmen, M. (1996). Kilkisna teoria groshey [The Quantitative theory of money]. Moskow: Elfpress [in Russian].

11. Sizonenko, V.O. (2012). Mehanizmi aktivizatsii innovatsiynoy dialnosti integrovanih korporativnih struktur [Mechanisms of activation of innovative activity of the integrated corporate structures] Teoretichni i prikladni pitannia economiki - The Theoretical and applied questions of economy: Collection of scientific works. Vol. 27, 1, 43-50. Kiyv: VPTS the «Kyiv university» [in Ukrainian].

12. Porter, M. (2001). Konkurencia [Competition]: trudged. with eng - Moskow of Publ. HouseWilliam [in Russian]. 